\title{
ANALISIS IDENTITAS MEREK, LOYALITAS MEREK, CITRA MEREK, DAN KEPERCAYAAN MEREK TOYOTA
}

\author{
Ade Jermawinsyah Zebuah \\ Manajemen Pemasaran, Sekolah Tinggi Ilmu Ekonomi Graha Karya Muara Bulian Jambi \\ E-mail: sainstolog@yahoo.co.id
}

\begin{abstract}
Abstrak:Kebutuhan konsumen atas kendaraan semakin meningkat, memicu setiap perusahaan mobil menciptakan identitas merek yang hebat dalam mendapatkan kepercayaan konsumen. Persepsi merek dari konsumen mempengaruhi untuk mendapatkan kepercayaan merek yang memiliki banyak hal untuk loyalitas merek. Penelitian ini bertujuan untuk menganalisis pengaruh identitas merek terhadap loyalitas merek dengan citra merek dan kepercayaan merek sebagai variabel intervening. Penelitian ini akan dilakukan dengan membagikan 100 kuesioner kepada responden yang telah membeli atau menggunakan Toyota. Teknik analisis yang akan digunakan adalah analisis kuantitatif dengan metode Smart-PLS. Penelitian menunjukkan bahwa identitas merek memengaruhi citra merek, tetapi tidak memiliki pengaruh terhadap kepercayaan merek, citra merek memengaruhi kepercayaan merek. Juga citra merek dan kepercayaan merek memengaruhi loyalitas merek Toyota.
\end{abstract}

Kata kunci: Brand Identity, Brand Image, Brand Trust, Brand Loyalty.

Abstract:Consumer needs in vehicles is increasing, it triggers any car companies to create great brand identity in order to gain brand trust from consumen. Perception of brand from consumen is affect to gain brand trust which is have great deal to brand loyalty. This research is aiming to analyze the influence of brand identity on brand loyalty with brand image and brand trust as an intervening variable. This research will be done by distributing 100 questionnairs to the respondents who have buy or used Toyota. Analysis techniques that will be used is quantitative analysis with Smart-PLS method. Research shows that brand identity influences brand image, but has no influences to brand trust, brand image influences brand trust. Also brand image and brand trust influences loyalty of Toyota's brand.

Keywords: Brand Identity, Brand Image, Brand Trust, Brand Loyalty.

\section{PENDAHULUAN}

Pertumbuhan ekonomi Indonesia mengalami peningkatan, Badan Pusat Statistik (BPS) melaporkan, produk domestik bruto ( PDB) atau pertumbuhan ekonomi Indonesia selama tahun 2017 mencapai 5,07 persen. Angka ini, menurut BPS, merupakan angka pertumbuhan ekonomi tertinggi sejak tahun 2014 silam. Angka pertumbuhan ekonomi pada tahun 2017 tersebut lebih rendah dari target yang dipasang pada Anggaran Pendapatan dan Belanja Negara (APBN), yakni 5,2 persen. Namun demikian optimistis ekonomi Indonesia ke depan bisa tumbuh lebih tinggi lagi. Peningkatan pendapatan tersebut memiliki korelasi positif kuat dengan daya beli masyarakat.

Meningkatnya daya beli terkait juga dengan kebutuhan konsumen terhadap mobilitas sosial yang dihadapi.Sebagian besar masyarakat bahkan menganggap kendaraan bermotor merupakan kebutuhan pokok.Hal ini juga didukung oleh penjualan mobil. Memang tahun 2017 naiknya sedikit dari 2016, hanya 1,6\% dari 1,06 juta," ," kata Ketua I Gaikindo, Jongkie Sugiarto dalam acara Prediksi Industri Otomotif Indonesia 2018 di UOB Plaza, Jakarta, Selasa (16/1/2017). Pertumbuhan penjualan mobil tersebut lebih rendah dari pertumbuhan di 2016. Saat itu penjualan mencapai 1,06 juta, naik $4,5 \%$ dari pen- jualan di 2015 sebesar 1,01 juta unit. Toyota menguasai pangsa pasar mobil 2017 dengan membukukan penjualan sebanyak 371.332 unit atau 34,40 persen. Toyota bersama empat pabrikan lainnya Honda, Daihatsu, Mitsubishi dan Suzuki mencatatkan penguasaan pasar mencapai 90,58 persen. Merek Toyota memiliki keunggulan di pangsa pasar mobil, karena telah dikenal secara luas di kalangan konsumen mobil. Ada beberapa alasan mengapa merek sangat penting bagi kesuksesan bisnis, antara lain: (1) Merek membedakan produk dengan produk pesaing, (2) Merek memberikan identifikasi bahwa sebuah produk berbeda dengan produk lainnya, (3) Identifikasi produk dan juga bermanfaat dalam hal iklan dan promosi, (4) Menambah nilai produk, konsumen melihat merek sebagai sebuah tolok ukur dan menambah nilai sebuah produk.

Merek dapat menambah image sebuah produk. Konsumen cenderung memilih produk yang bermerek karena lebih bisa dipercaya dan merasa aman. Kebutuhan mengelola merek akan lebih dirasakan oleh usaha yang menghadapi pesaingan ketat di pangsa pasarnya. Adanya beberapa manfaat merek tersebut, maka sukses membangun bisnis adalah dengan mengelola merek produk yang dimiliki. Produk yang baik akan lebih mudah dikenal jika memiliki merek tertentu. Identitas merek dikatakan 
sebagai karakteristik khas dari sebuah merek [4]. Identitas merek terdiri atas nama, logo, slogan suatu merek yang menggambarkan citra perusahaan atau produk tersebut. Dengan demikian identitas merek dapat diartikan sebagai persepsi merek yang khas dari sebuah perusahaan yang ingin disampaikan perusahaan sehingga membentuk persepsi konsumen mengenai merek tersebut.Keunikan identitas merek ini didefinisikan oleh konsumen bahwa merek tersebut tidak hanya memiliki produk yang baik tetapi juga memiliki reputasi yang baik, kualitas yang baik, serta memberi gengsi tersendiri bagi konsumen [14].

Persoalan citra merek merupakan salah satu hal yang juga harus diperhatikan perusahaan.Tanpa citra merek yang positif dan kuat, sangatlah sulit untuk menarik pelanggan baru dan mempertahankan yang sudah ada. Citra merek dapat diartikan sebagai penglihatan dan kepercayaan yang terpendam di benak konsumen sebagai cerminan asosiasi yang tertahan di ingatan konsumen [15].Dengan adanya pandangan dan pemikiran konsumen tentang suatu poduk dapat menimbulkan kepercayaan terhadap merek yang berujung pada loyalitas konsumen.

Kepercayaan merek merupakan adanya harapan atau kemungkinan yang tinggi merek tersebut akan mengakibatkan hasil yang positif terhadap konsumen [9]. Dari sudut pandang konsumen, kepercayaan merek merupakan suatu keyakinan akan suatu merek terhadap adanya pemuasan kebutuhan dilihat dari kredibilitas, integritas, keunggulan yang diletakkan pada merek tertentu [13].

Loyalitas merek merupakan suatu konsep yang sangat penting dalam strategi pemasaran.Keberadaan konsumen yang loyal pada merek sangat diperlukan agar perusahaan dapat bertahan. Loyalitas merek sebagai suatu ukuran keterkaitan pelanggan kepada sebuah merek yang mampu memberikan gambaran tentang mungkin tidaknya seorang pelanggan beralih ke merek lain yang ditawarkan oleh kompetitor, terutama jika pada merek tersebut didapati adanya perubahan, baik menyangkut harga ataupun atribut lainnya (Aaker, 2009). Seorang pelanggan yang sangat loyal kepada suatu merek tidak akan dengan mudah memindahkan ketergantungannya ke merek lain, apa pun yang terjadi dengan merek tersebut.

\section{TINJAUAN PUSTAKA}

\section{Identitas Merek}

Identitas merek terkait mengenai nama, logo, warna, tagline, dan simbol sebuah merek [16]. Identitas merek merupakan asosiasi merek yang unik yang menunjukkan janji kepada konsumen. Agar menjadi efektif, identitas merek perlu memiliki resonansi dengan consume. Hal ini bertujuan untuk dapat membedakan merek dengan pesaing, serta dapat menjelaskan apa yang akan dilakukan perusahaan dalam menjaga keberlanjutannya [3].

\section{Citra Merek}

Citra merek merupakan serangkaian asosiasi yang ada dalam benak konsumen terhadap suatu merek, biasanya terorganisasi menjadi suatu makna [1]. Citra merek juga dikatakan sebagai penglihatan dan kepercayaan yang terpendam di benak konsumen sebagai cerminan asosiasi yang tertahan di ingatan konsumen [17].Citra merek dapat diukur melalui tiga kategori:

1. Favorability of brand association

Suatu merek menciptakan sikap yang positif jika atribut dan manfaat merek tersebut dapat memuaskan kebutuhan dan keinginan konsumen.

2. Strength of brand association

Asosiasi yang terbentuk dari informasi yang masuk kedalam ingatan konsumen dan bagaimana informasi tersebut bertahan sebagai bagian dari brand image

3. Uniqueness of brand association

Merek yang unik dan menarik mampu menimbulkan asosiasi yang kuat di dalam pikiran pelanggan

\section{Kepercayaan Merek}

Kepercayaan merek merupakan kemampuan merek untuk dipercaya, bersumber pada keyakinan konsumen bahwa produk tersebut mampu memenuhi nilai yang dijanjikan, dan didasarkan pada keyakinan konsumen bahwa merek yang ditawarkan mampu mengutamakan kepetingan konsumen, (Delgado, 1999).

Terdapat tiga faktor yang mempengaruhi kepercayaan terhadap merek.Ketiga faktor ini merupakan tiga entitas yang tercakup dalam hubungan antara merek dan konsumen, (Lau dan Lee, 1999). Hubungan ketiga faktor tersebut dengan kepercayaan merek dapat digambarkan sebagai berikut:

1. Brand characteristic mempunyai peran yang sangat penting dalam menentukan analisa dan evaluasi konsumen untuk mempercayai suatu merek. Hal ini disebabkan oleh konsumen melakukan penilaian sebelum percaya pada merek, meliputi tingkat komitmen akan nilai unik yang diasosiasikan terhadap merek [5].

2. Company characteristic yang ada di balik suatu merek juga dapat mempengaruhi tingkat kepercayaan konsumen terhadap merek tersebut. 
Pengetahuan konsumen tentang perusahaan yang ada di balik merek suatu produk merupakan dasar awal pemahaman konsumen terhadap merek suatu produk. Karakteristk ini meliputi reputasi suatu perusahaan, motivasi perusahaan yang diinginkan, dan integritas suatu perusahaan.

3. Consumer-brand characteristic merupakan dua kelompok yang saling mempengaruhi. Karakteristik ini meliputi kemiripan antara konsep emosional konsumen dengan kepribadian merek, kesukaan terhadap merek, dan pengalaman terhadap merek.

\section{Loyalitas Merek}

Loyaliats merek sebagai suatu ukuran keterkaitan pelanggan kepada sebuah merek. Ukuran ini mampu memberikan gambaran tentang mungkin tidaknya seorang pelanggan beralih ke merek lain yang ditawarkan oleh pesaing, terutama jika pada merek tersebut didapati adanya perubahan baik menyangkut harga atau atribut lainnya, (Aaker, 2009). Terdapat dua aspek dari loyalitas merek, yaitu: perilaku (behavioral) dan sikap (attitude). Perilaku meliputi pembelian secara berulang dari sebuah merek, sedangkan sikap meliputi tingkat komitmen akan nilai unik yang diasosiasikan terhadap merek (Chaudhuri dan Holbrook, 2001).

\section{Kerangka Hipotesis}

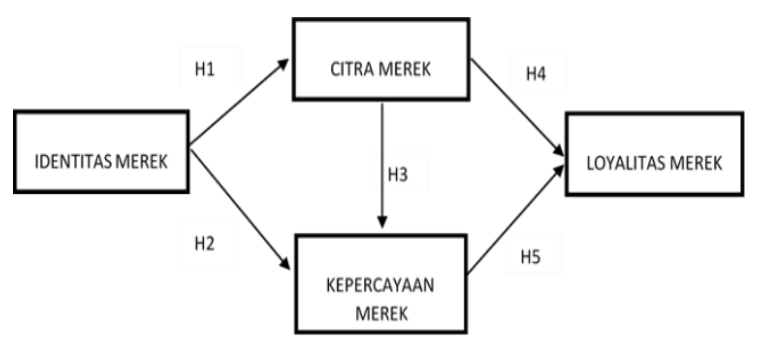

Gambar 1.Kerangka Hipotesis

\section{Hipotesis Penelitian}

Berdasarkan kerangka diatas, diperoleh hipotesis:

$\mathrm{H}_{1}$ : Identitas merek berpengaruh terhadap citra merek Toyota.

$\mathrm{H}_{2}$ : Identitas merek berpengaruh terhadap kepercayaan merek Toyota.

$\mathrm{H}_{3}$ : Citra merek berpengaruh terhadap kepercayaan merek Toyota.

$\mathrm{H}_{4}$ : Citra merek berpengaruh terhadap loyalitas merek Toyota.

$\mathrm{H}_{5}$ : Kepercayaan merek berpengaruh terhadap loyalitas merek Toyota.

\section{METODE PENELITIAN}

\section{Populasi dan Sampel}

Populasi yang digunakan adalah semua masyarakat Jambi yang mengetahui merek Toyota.Dengan meneliti sebagian dari populasi, diharapkan bahwa hasil yang didapat mampu menggambarkan populasi yang bersangkutan.Sampel yang diteliti oleh peneliti adalah 100 masyarakat Jambi yang pernah menggunakan atau membeli merek Toyota.

\section{Teknik Pengambilan Sampel}

Sampel penelitian dipilih menggunakan purposive sampling yang merupakan tekniknonprobabilitysampling artnya setiap individu sampel dipilih dari populasi tanpa menggunakan peluang tertentu [21].

\section{Teknik Pengumpulan Data}

Teknik pengumpulan data dikaitkan dengan kebutuhan data yang akan digunakan. Untuk itu bentuk pengumpulan data terdiri dari:

\section{Dokumentasi}

Dokumentasi adalah mencari dan mengumpulkan data mengenai hal-hal yang berupa catatan, transkrip, buku, surat kabar, majalah, notulen, rapot, agenda, dan sebagainya [22].

2. Kuesioner

Teknik pengumpulan data yang dilakukan dengan cara memberi seperangkat pertanyaan atau pernyataan tertulis kepada responden untuk dijawab [22]. Dalam penelitian ini, kuesioner akan diberikan kepada msayarakat Jambi yang pernah menggunakan atau membeli merek Toyota dan diukur dengan skala likert.

\section{Definisi Operasional Variabel}

1. Variabel Eksogen

Variabel yang tidak diprediksi oleh variabel lain dalam model [11].Variabel eksogen dalam penelitian ini adalah identitas merek yang diukur dari warna, logo, tagline.

\section{Variabel Intervening}

Variabel yang mempengaruhi hubungan antara variabel eksogen dan endogen, tetapi tidak dapat diamati dan diukur.Dalam penelitian ini variabel intervening adalah citra merek yang diukur dari favourability, strength, uniqueness dan kepercayaan mrek yang diukur dari brand characteristics, company characteristics, consumer brand characteristics. 
3. Variabel Endogen

Variabel yang diprediksikan oleh satu atau beberapa variabel yang lain dalam model [11]. Dalam penelitian ini, variabel endogen adalah loyalitas merek Toyota yang diukur dari purchase dan attitudinal

\section{Metode Analisis Data}

1. Uji Validitas dan Reliabilitas

Uji validitas digunakan untuk mengukur valid atau tidaknya suatu kuesioner. Hasil penelitian dikatakan valid bila terdapat kesamaan antara data yang terkumpul dengan data yang sesungguhnya terjadi pada obyek yang diteliti [18]. Sedangkan uji reliabilitas digunakan untuk memastikan bahwa respoden cukup konsisten. Pengujian ini dilakukan dengan nilai cronbrach's alpha. Jika cronbrach's alpha yang dinyatakan dalam koefisien reliabel atau " $\alpha$ " > 0,60 maka jawaban konsumen dikatakan reliabel sehingga data tersebut layak untuk digunakan dalam penelitian selanjutnya [18].

\section{Partial Least Square}

Metode penelitian yang digunakan adalah SMART-PLS, yang pertama kali diikembangkan oleh [23]. Analisis dengan PLS menerapkan dua tahap penting yaitu the measurement model dan structural model. Data dalam measurement model (outer model) dievaluasi untuk menentukan validitas dan reliabilitasnya. Bagian dari tahap itu meliputi:

1. individual loading dari setiap pertanyaan

2. internal composite reliability (ICR)

3. average variance extracted (AVE)

4. discriminant validity [6]

Dalam structural model (inner model), meguji hipotesis yang hasilnya ditunjukkan melalui signifikansi dari:

1. path coefficients (standardised beta)

2. T-statistics

3. R-squared value

Goodness of Fit Model diukur menggunakan $R$ square variable laten dependen dengan interpretasi yang sama dengan regresi, $Q$-squarepredictive relevance untuk model struktural, mengukur seberapa baik nilai observasi dihasilkan oleh model dan juga estimasi parameternya. Nilai $Q$ square $\leq 0$ menunjukkan model kurang memiliki predictive relevance sebaliknya jika nilai $Q$ square $>0$ menunjukkan model memiliki predictive relevance,dimana ketika hasil mendekati 1 maka model semakin baik.

\section{PEMBAHASAN}

\section{Deskriptif Profil Responden}

Dari total 100 responden, terdapat 50 laki-laki dan 50 wanita dengan usia terbanyak berada di range 31-40 tahun sebanyak 29\% dan bekerja sebagai pegawai swasta sebanyak 52\%. Diketahui juga bahwa 40\% memiliki penghasilan kurang dari Rp 10.000.000,- dengan penggunaan BBM/bulan Rp $1.000 .000,--\operatorname{Rp} 2.000 .000$,- sebanyak $37 \%$.

\section{Analisa Validitas dan Reliabilitas}

Hasil uji validitas pada item pertanyaan semua variabeldiketahui nilai corrected item-total correlation dari identitas merek, citra merek, kepercayaan merek, loyalitas merek sudah lebih besar dari $\mathrm{r}$ tabel 0,30 . Sementara itu, uji reliabilitas identitas merek memiliki cronbach alpha 0,943, citra merek 0,968, kepercayaan merek 0,959 , loyalitas merek 0,935 . Ini menunjukkan nilai cronbach alpha lebih besar dari 0,60 . Kedua hasil tersebut menunjukkan bahwa semua variabel dapat dilanjutkan pada tahap pengujian.

Tabel 1.Indicator Reliability

\begin{tabular}{|c|c|c|c|c|}
\hline Latent Variable & Indicator & Loading & $\begin{array}{c}\text { Indicator } \\
\text { Reliability }\end{array}$ & Kesimpulan \\
\hline \multirow{5}{*}{ Identitas Merek } & BI1 & 0,8592 & 0,738 & Baik \\
\hline & BI2 & 0,8496 & 0,722 & Baik \\
\hline & $\mathrm{BI} 3$ & 0,8381 & 0,702 & Baik \\
\hline & $\mathrm{BI} 4$ & 0,8740 & 0,764 & Baik \\
\hline & BI5 & 0,8496 & 0,722 & Baik \\
\hline \multirow{9}{*}{ Citra Merek } & BM1 & 0,8490 & 0,717 & Baik \\
\hline & BM2 & 0,8468 & 0,715 & Baik \\
\hline & BM3 & 0,8457 & 0,719 & Baik \\
\hline & BM4 & 0,8478 & 0,719 & Baik \\
\hline & BM5 & 0,8481 & 0,712 & Baik \\
\hline & BM6 & 0,8440 & 0,737 & Baik \\
\hline & BM7 & 0,8584 & 0,748 & Baik \\
\hline & BM8 & 0,8650 & 0,757 & Baik \\
\hline & BM9 & 0,8703 & 0,723 & Baik \\
\hline \multirow{9}{*}{$\begin{array}{c}\text { Kepercayaan } \\
\text { Merek }\end{array}$} & BT1 & 0,8505 & 0,720 & Baik \\
\hline & $\mathrm{BT} 2$ & 0,8484 & 0,722 & Baik \\
\hline & BT3 & 0,8496 & 0,768 & Baik \\
\hline & BT4 & 0,8766 & 0,736 & Baik \\
\hline & BT5 & 0,8578 & 0,711 & Baik \\
\hline & BT6 & 0,8433 & 0,720 & Baik \\
\hline & BT7 & 0,8484 & 0,721 & Baik \\
\hline & BT8 & 0,8542 & 0,730 & Baik \\
\hline & BT9 & 0,8493 & 0,721 & Baik \\
\hline \multirow{4}{*}{ Loyalitas Merek } & BL1 & 0,8480 & 0,719 & Baik \\
\hline & BL2 & 0,8470 & 0,717 & Baik \\
\hline & BL3 & 0,8452 & 0,714 & Baik \\
\hline & BL4 & 0,8759 & 0,767 & Baik \\
\hline
\end{tabular}




\section{Partial Least Square}

1. Evaluasi Indicator Reliability

Langkah awal untuk memeriksa apakah indikatorindikator yang digunakan untuk mengolah data dapat dikatakan reliabel yaitu dengan melakukan uji reliabilitas menggunakan indicator reliability. Nilai indikator didapatkan dari hasil pangkat dua dari outer loading, dan dikatakan baik jika nilainya diatas 0,70 . Berikut merupakan nilai outer loading yang sudah diolah menjadi indicator reliability seperti tabel 1 .

Dapat disimpulkan bahwa variabel identitas merek, citra merek, kepercayaan merekdan loyalitas merekmemiliki nilai indicator reliability yang lebih besar dari 0,70. Dengan demikian evaluasi indicator reliability setiap indikator sudah baik dan sesuai.

\section{Evaluasi Internal Consistency Reliability}

Tabel 2.Internal Consistency Reliability

\begin{tabular}{|l|c|}
\hline \multicolumn{1}{|c|}{ Variabel } & Composite Reliability \\
\hline Identitas merek & 0,930983 \\
\hline Citra Merek & 0,960008 \\
\hline Kepercayaan Merek & 0,960113 \\
\hline Loyalitas Merek & 0,915147 \\
\hline
\end{tabular}

Keseluruhan variabel memiliki nilai composite reliability diatas 0,60 , sehingga dapat disimpulkan bahwa keseluruhan variabel memiliki level internal consistency reliability yang tinggi.

3. Evaluasi Convergent Validity

Convergent validity dilihat dari nilai AVE setiap variabel laten. Jika tiap variabel menghasilkan nilai lebih besar dari kriteria 0,50, maka disimpulkan telah memenuhi validitas secara [6].Berikut ini adalah hasil validitas konvergen masingmasing variabel:

Tabel 3. Convergent Validity

\begin{tabular}{|l|c|c|}
\hline \multicolumn{1}{|c|}{ Variabel } & $A V E$ & Keterangan \\
\hline Identitas Merek & 0,7296 & Valid \\
\hline Citra Merek & 0,7273 & Valid \\
\hline Kepercayaan Merek & 0,7279 & Valid \\
\hline Loyalitas Merek & 0,7295 & Valid \\
\hline
\end{tabular}

Tabel 4 di atas menunjukkan bahwa keseluruhan variabel yang digunakan pada penelitian ini memiliki $A V E$ lebih besar dari 0,50. Dengan demikian maka evaluasi convergent validity sudah baik.
4. Evaluasi Discriminant Validity

Discriminant validity adalah evaluasi selanjutnya pada uji validitas dalam analisis PLS. Discriminant validity berbeda dengan convergent validity yang telah dijelaskan sebelumnya. Discriminant validity dilakukan dengan melihat nilai akar kuadrat dari $A V E$ yang harus lebih besar daripada nilai korelasi antar variabel laten [6].

Tabel 4. Analysis for Checking Discriminant Validity

\begin{tabular}{c|c|c|c|c}
\hline & BI & BM & BT & BL \\
\hline BI & $\mathbf{0 , 8 5 4 1 6 6}$ & & & \\
\hline BM & 0,773830 & $\mathbf{0 , 8 5 2 8 1 9}$ & & \\
\hline BT & 0,401675 & 0,481605 & $\mathbf{0 , 8 5 3 1 7 1}$ & \\
\hline BL & 0,495192 & 0,532744 & 0,627346 & $\mathbf{0 , 8 5 4 1 0 8}$ \\
\hline
\end{tabular}

Tabel 4 menunjukkan bahwa tiap variabel pada penelitian ini memiliki nilai lebih besar daripada nilai korelasi antar variabel laten. Dengan demikian maka evaluasi discriminant validity sudah baik. Untuk hubungan identitas merek dan citra merek memiliki $A V E$ dan korelasi yang sangat dekat, untuk itu perlu dikaji lebih mendalam indikator yang menjadi pembeda antara dua variabel tersebut.

5. Evaluasi Inner Model

Evaluasi atas innermodel di dalam analisa partial least square dilakukan untuk mengetahui kesesuaian model struktural yang telah disusun. Dalam evaluasi inner model akan diuraikan nilai $R$ square $\left(\mathrm{R}^{2}\right)$ dan pengujian hipotesis penelitian.

a. R-square

Berdasarkan pengolahan data dengan PLS, dihasilkan nilai koefisien determinasi $(R$ square) sebagai berikut:

Tabel 5. Nilai $R$-square Model

\begin{tabular}{|l|c|}
\hline \multicolumn{1}{|c|}{ Variabel } & $\boldsymbol{R}$-square \\
\hline Identitas Merek & \\
\hline Citra Merek & 0,598 \\
\hline Kepercayaan Merek & 0,234 \\
\hline Loyalitas Merek & 0,462 \\
\hline
\end{tabular}

$R$-square digunakan untuk mengetahui goodness of fit model pengaruh dari variabel eksogen terhadap variabel endogen, dimana semakin tinggi nilai $R$-square maka akan semakin signifikan pengaruh yang diberikan [12]. Diketahui nilai $R$-square untuk variabel citra merek adalah sebesar 0,598 yang memiliki arti bahwa identitas merekdari merek 
Tabel 6. Pengaruh Antar Variabel Dalam Persamaan Struktural \& Pengujian Hipotesis

\begin{tabular}{|c|l|c|c|c|c|}
\hline Hipotesis & \multicolumn{1}{|c|}{ Hubungan } & $\begin{array}{c}\text { Original } \\
\text { Sample } \\
(\mathrm{O})\end{array}$ & $\begin{array}{c}\text { TStatistics } \\
(\mid \mathrm{O} / \text { STERR })\end{array}$ & Signifikan & Keterangan \\
\hline H1 & Identitas Merek $-\rightarrow$ Citra Merek & 0,774 & 15,222 & 0,000 & Diterima \\
\hline H2 & Identitas Merek $-\rightarrow$ Kepercayaan Merek & 0,072 & 0,452 & 0,652 & Ditolak \\
\hline H3 & Citra Merek $-\rightarrow$ Kepercayaan Merek & 0,425 & 2,926 & 0,004 & Diterima \\
\hline H4 & Citra Merek $-\rightarrow$ Loyalitas Merek & 0,300 & 3,353 & 0,001 & Diterima \\
\hline H5 & Kepercayaan Merek - $\rightarrow$ Loyalitas Merek & 0,483 & 6,021 & 0,000 & Diterima \\
\hline
\end{tabular}

Toyota dapat menjelaskan citra mereksebesar $59,8 \%$. Untuk nilai $R$-square pada variabel kepercayaan merek diperoleh nilai sebesar 0.234 yang memiliki arti bahwa identitas merek dan citra merek dari merek Toyota dapat menjelaskan kepercayaan merek sebesar 23,4\%. Sementara nilai $R$-square untuk variabel loyalitas merek adalah sebesar 0,462 yang menerangkan bahwa citra merek dan kepercayaan merekdari merek Toyota dapat menjelaskan loyalitas merek sebesar 46,2\%.

Secara keseluruhan ukuran kebaikan dari model struktural PLSdiketahui dari nilai $\mathrm{Q}^{2}$ yang dihasilkan oleh modeldan juga estimasi parameternya. Semakin tinggi $\mathrm{Q}^{2}$, maka model dapat dikatakan semakin fit dengan data [12]. Berikut adalah perhitungan $\mathrm{Q}^{2}$ pada model struktural.

$$
\begin{aligned}
Q^{2} & =1-\left\{\left(1-{R_{1}}^{2}\right)\left(1-R_{2}{ }^{2}\right)\left(-R_{3}{ }^{2}\right)\right\} \\
Q^{2} & =1-\left\{\begin{array}{c}
(1-0,598)(1-0,234) \\
(1-0,462)
\end{array}\right\} \\
Q^{2} & =1-\{0,166\} \\
Q^{2} & =0,834
\end{aligned}
$$

Dari hasil didapatkan bahwa nilai $\mathrm{Q}^{2}$ sebesar $83,4 \%$. Nilai $\mathrm{Q}^{2}$ menunjukkan bahwa penyusunan model PLS telah mampu menjelaskan 83,4\% keragaman dari identitas merek, citra merek, kepercayaan merekdan loyalitas merekmerek Toyota.

b. Inner Weight

Evaluasi atas inner weight digunakan untuk melihat besarnya pengaruh yang ada pada setiap jalur model struktural dimana nilai-nilai yang didapatkan ini merupakan nilai hasil bootstrapping dari sampel yang ada.

Dilihat dari gambar 2, ditemukan hasil nilai nilai bootstrapping dengan sample sebesar 200 menghasilkan nilai estimasi T-statistics sebagai pada tabel 6 .

Pengaruh antar variabel dikatakan bersifat signifikan apabila nilai $T$-statistics lebih besar dari angka 1,96. Sehingga diketahui bahwa berdasarkan Tabel 6, terdapat pengaruh antara identitas merek terhadap citra, citra merek terhadap kepercayaan merek, citra merek dan kepercayaan merek terhadap loyalitas merek, namun tidak terdapat pengaruh antara identitas merek terhadap kepercayaan merek.

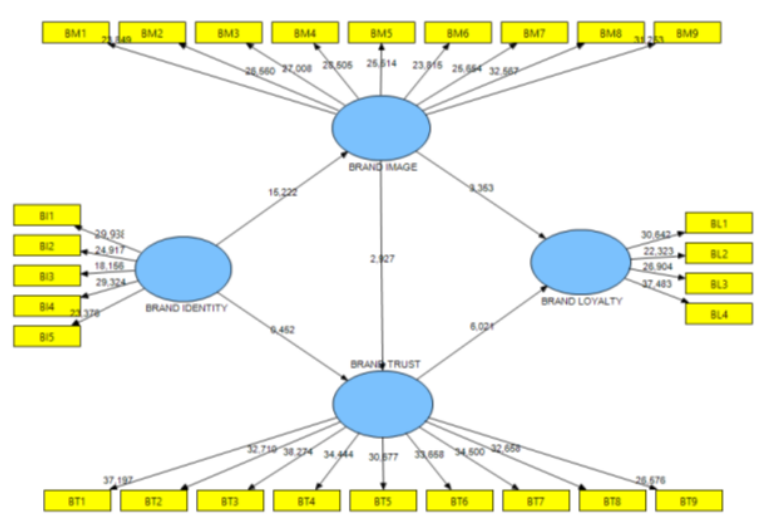

Gambar 2.Nilai t-Statistik Estimasi Koefisien Jalur

\section{Pembahasan}

Perngaruh identitas merek terhadap Citra Merek, hasil penelitian menunjukkan bahwa identitas merek memiliki pengaruh positif terhadap citra merek Toyota. Hasil ini didukung dengan penelitian [7], menggambarkan bahwa, semakin baik identitas merek yang dibentuk oleh perusahaan, semakin baik pula citra merek di mata konsumen, sebaliknya apabila identitas merek yang dibentuk oleh perusahaan buruk, maka citra merek di mata konsmen akan buruk. Identitas merek ternyta tidak berpengaruh positif terhadap kepercayaan merek, dalam hasil penelitian menunjukkan bahwa identitas merek tidak memiliki pengaruh terhadap kepercayaan merek.Hasil ini didukung dengan penelitian [10], disimpulkan bahwa semakin baik identitas merek tidak berdampak pada kepercayaan merek di mata konsumen.Citra merek berpengaruh terhadap Kepercayaan merek, terlihat dari hasil penelitian menunjukkan bahwa citra merek memiliki pengaruh positif terhadap kepercayaan merek. Hasil ini didukung dengan penelitian 
terdahulu [20]. Dapat disimpulkan bahwa semakin baik citra merek yang diciptakan oleh suatu perusahan, maka semakin baik pula kepercayaan terhadap merek di mata konsumen.Citra merek berpengaruh terhadap loyalitas merek yang ditunjukan oleh hasil penelitian bahwa citra merek memiliki pengaruh positif terhadap loyalitas merek, temuan ini mendukung penelitian [19], disimpulkan bahwa semakin baik citra merek perusahaan semakin baik pula loyalitas merek di mata konsumen. Kepercayaan merek berpengaruh terhadap loyalitas merek, terlihat dari hasil penelitian bahwa kepercayaan merek memiliki pengaruh positif terhadap loyalitas merek, didukung dengan penelitian terdahulu yang dilakukan oleh [20], disimpulkan bahwa semakin baik kepercayaan merek semakin baik pula loyalitas pada merek.

\section{KESIMPULAN}

Atas dasar analisis yang telah dilakukan diambil beberapa kesimpulan antara lain:

1. Identitas merek berpengaruh terhadap citra merek. Dimana berarti warna, logo, tagline yang dijelaskan oleh perusahaan memiliki pengaruh terhadap peningkatan citra merek.Ini berarti definisi identitas Toyota sudah jelas tersampaikan pada konsumen sehingga konsumen dapat mempersepsikannya dengan baik.

2. Identitas merek tidak berpengaruh terhadap kepercayaan merek. Dimana berarti wana, logo, tagline yang dijelaskan dalam perusahaan tidak berpengaruh secara nyata atas timbulnya kepercayaan dari konsumen.

3. Citra merek berpengaruh terhadap kepercayaan merek. Hal ini menjelaskan bahwa citra merek yang diprsepsikan oleh konsumen mempengaruhi timbulnya kepercayaan konsumen. Citra merek yang dipersepsikan oleh konsumen seperti adanya pandangan tentang kualitas, servis, perusahaan baik mampu membuat konsumen percaya pada Toyota.

4. Citra merek juga berpengaruh terhadap loyalitas merek. Hal ini menjelaskan bahwa citra merek yang dipersepsikan oleh konsumen secara positif mampu mempengaruhi timbulnya loyalitas merek secara positif juga.

5. Kepercayaan merekberpengaruh terhadap loyalitas merek. Hal ini menjelaskan bahwa loyalitas pada merek yang dijabarkan melalui rekomendasi konsumen, selalu membeli merek Toyota, menjadikan pilihan pertama, mau membayar lebih mahal didapat dari kepercayaan konsumen.Semakin tinggi tingkat kepercayaan konsumen pada Toyota, maka tingkat pada loyalitas merek juga ikut meningkat.

\section{DAFTAR PUSTAKA}

Aaker, D. (1994). Building a brand: The saturn Story. California Management Review, 36 (2), 104-113.

Aaker, D. (2009). Manajemen Ekuitas Merek. Jakarta: Spektrum.

Aaker, D., and Joachimsthaler, E. (2000). Brand leadership. New York: The Free Press.

Bhattacharya. C. B., and Ahearne, M. (2005). Antecedents and consequences of $\mathrm{c}-\mathrm{c}$ identification expanding the role of relationship marketing. Journal of American Psychological Association, Vol. 90, No. 3, 574-585.

Chaudhuri, A., and Holbrook, M. (2001). The chain of effects from brand trust and brand affect to brand performance. The role of brand loyalty. Journal of Marketing, Vol. 37, No. 11, pp. $1762-1800$.

Chin, et all. (2010). A partial least squares latent variable model approach for measuring interaction effects: results from a monte carlo simulation study and an electronic mail emotion. Information Systems Research, Vol 14, pp 353363.

Davis, S. M., and Chun, R. (2006).Coorporate reputation and competitiveness.London: Routledge.

Delgado, B., Elena, dan Jose. (1999). Brand trust in the context of consumer loyalty. European Journal of Marketing, 35 (11/12), 1238-1258.

Delgado. B., dan Manuera-Aleman.(2005). Does brand trust matter to brand equity.The Journal of Product and Brand Management, 14 (2/3), 187196.

Doney, P. M., dan Canon, J. P. (1997). An examination of the nature of trust in buyer-seller relationships. Jounal of Marketing, 46, 92-101.

Ferdinand, A. (2002). Strctural equation modelling dalam penelitian manajemen ( $\left.2^{\text {nd }} e d\right)$. Semarang: BP Undip.

Ghozali, I. (2011). Aplikasi analisis multivariate dengan program SPSS. Semarang: Universitas Diponegoro.

Gurviez, Patricia, dan M. Korchia. (2003). Test of a consumer-brand relationship model including trust and three consequences.Makalah Seminar dalam 30 tahun International Research Seminar in Marketing.

Kirmani, A., Sood, S., dan Bridges, S. (1999). The ownership effect in consumer responses to brand line stretches. New Jersey: Prentice Hall.

Kotler, P. (2002). Manjemen pemasaran. Jakarta: Salemba

Kotler, P., dan Armstrong, G. (2003).Dasar-dasar pemasaran.Jakarta : Erlangga

Kotler, P., dan Pfoertsch, W. (2008).B2B brand management. Jakarta: PT. Bhuana Ilmu Populer.

Malhotra, N.K. (2012). Marketing research: integration of social media $\left(4^{\text {th }} e d\right)$. London: Orientation Prentice Hall. 
Neria, M. (2012). Pengaruh citra merek terhadap loyalitas konsumen maskapai penerbangan garuda indonesia. Jakarta: Universitas Indonesia

Rizan, S. (2012). Pengaruh brand image dan brand trust terhadap brand loyalty teh botol sosro. Jurnal Riset Manajemen Sains Indonesia. Jakarta: Universitas Negeri Jakarta.
Silalahi, G. (2003). Metodologi dan studi kasus. ( $1^{\text {sted}}$. Jakarta: CV. Citramedia.

Sugiyono. (2012). Memahami penelitian kualitatif. Bandung: ALFABETA

World, H. (1980). Panduan teknik statistik SEM \& PLS dengan SPSS AMOS. Yogyakarta: Mustafa. 